\section{CLAY MINERALS AND THE ORIGIN OF LIFE}

\section{A.G. Cairns-Smith and H. Hartman (eds.)}

Cambridge University Press, Cambridge, London, New York, Melbourne, Sydney, 1986, 193p., (C) $\$ 34.50$ (US)

Amongst the many compelling points in the Genesis narrative in the Bible is the notion that mankind was formed from the dust or clay of the earth. The idea has fascinated writers and poets through the millennia, so that Wilfred Owen, seeing massacre and the spoiling of the Earth before him, could lament "Was it for this the clay grew tall? - $\mathrm{O}$ what made fatuous sunbeams toil / To break Earth's sleep at all?"

In this century, when the debate about the origin of life has taken on a predominantly chemical, erystallographic and often Marxist (as opposed to Biblical) language, there has lingered the fascination with clay. Quite simply, clay is wonderful stuff and excellent material to serve as midwife, as a eatalyst in the first synthesis of life. We still cannot define life, but nevertheless, it seems excellent to guess that somehow clay took a role in creating something that we do not understand but choose to name "life".

What was that "something?" We would probably name as life anything that has the properties of von Neumann's famous self-replicating machine. All modern life is organic, but Cairns-Smith in 1966 made the interesting suggestion that the first life could have been in that very dust of Genesis, that it may have begun as a self-replicating structure of clay, with the first genetic material clay minerals. Since then, Cairns-Smith and his disciples have built up a powerful case for the "clay first" hypothesis, arguments for which have been expanded in a variety of books and scientific papers.

The case is interesting and now detailed. It is not, of course, proven, though one of the more enthusiastic of the disciples remarked recently that he fully expected it to be so in the next year or two. Nevertheless, it is amongst the most powerful of the contending theories for the origin of life, the present favourite perhaps being the "RNA-first" world.

The present volume explores the clay-first hypothesis in detail, but it does much more than that and is a very valuable and very informative compilation of all things clayey. It begins with a historical introduction, and then moves to a general crystallographic introduction to the horrendous complexity of the clay family. This is followed by a lucid discussion of the synthesis of clays, with (for a geologist) a nice exposition of time-temperature-transformation problems. Life is disequilibrium: thus presumably its origin is a matter of activation energy, entropy and Ostwald's step rule, whether it began as clay or nucleic acid.

Next comes a set of papers about clays on the early Earth. Now all Archaean geologists know how rare pelitic assemblages are in the Archaean: they do exist, but there are not many. Perhaps hydrothermal clays would be a better bet, or some of the most open hydrothermal zeolites. On the other hand, in a typically elegant paper Arrhenius suggests that the modern banded ironstones of the Red Sea may provide an analogue for the Archaean sea floor. Possibly some iron oxide hydroxides could have been important, or perhaps iron phosphate structures such as cacoxenite.

There is much more in the book. A section on clays in the solar system follows, and then "clays as catalysts". Finally comes a discussion on clays as genes. This is an exposition of the present status of the clay-first hypothesis, linked to an epilogue that is a dialogue between the two editors.

In general, this is an excellent book, filled with all sorts of extraordinary details about its hero, clay. The focus is on the origin of life, but there is much that is of more general interest, even, in some of the discussion about diagenesis, to petroleum geologists. A specialist but interesting volume no need to become a disciple to gain from it. The clay-first theory still seems to me to be most improbable, but well worth thinking about. Delbruk once commented that he would not read "Origin of Life" literature until someone had claimed to have made something that crawled out of a test-tube: he would thus have missed this volume, and have missed much.

E.G. Nisbet

Saskatoon, Canada

\section{HOW TO BUILD A HABITABLE PLANET}

Wallace S. Broecker

Eldigio Press, New York, 1985, 291p., (S) $\$ 18$, (H) $\$ 30$ (US)

This is a delightful book. Within the compass of 274 pages of text the author transports the reader from the mysteries of the "Big Bang" to the dangers of "Big Bucks". He accomplishes this with élan, panache, humour and accuracy. I smiled frequently and guffawed a least once - where the author refers to the attribution of the doubling of the methane content of the atmosphere to the steep rise in cattle population as the "McDonald's Syndrome".

The scope of the book is very

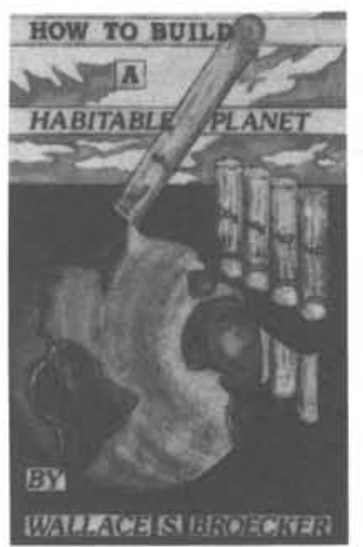
large. The choice of topics therefore reflects the author's interests and expertise. Professor Broecker spends the first 194 pages discussing the Big Bang and galaxy formation, the synthesis of the elements in stars, the formation of planets, the segregation of the Earth's core, mantle, crust, ocean and atmosphere, and the nature and history of moons, asteroids and comets. The remaining 80 pages deal with running water and the temperature controls of the Earth, with natural resources, and with the present and potential effects of mankind on the Earth as a habitable planet.

All of these subjects are treated well, and I found few discussions with which I disagreed. I did feel that Broecker underplayed the difficulties of explaining the intensity of the 100,000 year period in the glacial cycles in terms of 


\section{Book Reviews}

orbital processes, and I believe that the author's explanation of Precambrian banded iron formations is outdated and deserves much less than a seven on his scale of probability. Perhaps the weakest part of the book is the chapter on natural resources. Several of the resources chosen for discussion (e.g. sulphur and diamonds) are not major parts of the resource picture. I would have preferred something on aluminum and copper ores. In his enthusiasm for water as a mechanism for generating ore deposits, Broecker slights the magmatic processes that have given us our chromium and platinum ores, as well as major ore deposits of nickel and copper.

The book is based on notes for an undergraduate course taught by Professor Broecker between 1981 and 1985 for students at Columbia College and Barnard College. The course must have been most interesting and stimulating. It may also have been unique. Few courses today will be able to adopt How to Build a Habitable Planet as a text. This is a pity. Perhaps the book will stimulate a rethinking of the materials covered in undergraduate earth science courses. In any case, it will give a great deal of instruction and enjoyment to all of its readers. (Editor's note: Wallace Broecker's experience of desk-top publishing in producing this book is described in Nature, March 12, 1987, p207.)

H.D. Holland

Cambridge, Massachusetts

\section{RECENT EARTH MOVEMENTS: AN INTRODUCTION TO NEOTECTONICS}

\section{Vita-Finzi}

Academic Press, London, San Diego, New York, Austin, Montreal, Sydney, Tokyo, Toronto, 1986, 226p., (P) \$25 (US), (C) $\$ 50$ (US)

"Fortunately most earth scientists combine herd instinct with a strong exploratory urge." In these words Vita-Finzi publicly confesses that geologists are human. We suffer as others do from a tendency to fall into vogue thought processes, but we are to some extent rescued from eternal damnation by our innate curiosity, our collective urge to explore.

In his first chapter, the author deftly reviews the history of knowledge about recent earth movements, touching lightly on

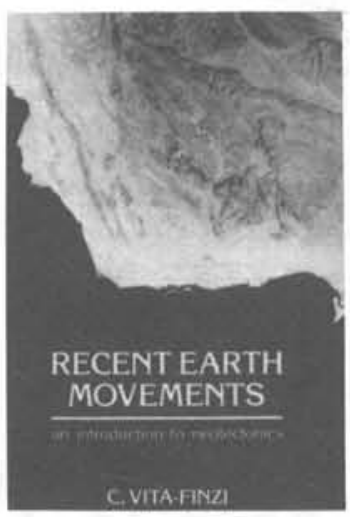
some of those fashionable paradigms that seemed like the tablets of Moses in their day. Vita-Finzi underlines the wisdom of Sir Charles Lyell, who chose to illustrate his Principles (from the 10 th edition onwards) with a frontispiece of the famous so-called "Temple of Serapis" at Pozzuoli. This is surely one of the most enduring and oftphotographed objects illustrating the theme of this volume. It still forces the old question; did the land sink or sea level rise? Although the relative motions are a matter of historical record, absolute values of tectonic and eustatic components are still a matter of contention.

The expression "recent earth movements" is employed here in its relative sense, which is a synonym for Obruchev's definition (of 1948) of "neotectonics" as any late Cenozoic to contemporary crustal motion. As the author's figure 8 (taken from earlier work by Kasahara) shows, crustal motions can be identified on time scales ranging from $10^{-2}$ seconds all the way up to $10^{8} \mathrm{yr}$, but the professional expertise involved calls for specialists in different disciplines. Seismologists are needed for the higher frequencies, geodesists around the 1 to $10^{2} \mathrm{yr}$ range, geomorphologists overlapping the latter and reaching to the $10^{6}$ $\mathrm{yr}$ range, and then the structural geologists taking over the $10^{6}$ to $10^{8}$ yr scales.

These different professionals all have different international associations and rarely even meet one another. Besides the Neotectonies Commission of INQUA, there is, for example, the Commission on Recent Vertical Crustal Movements of the International Union of Geodesy and Geophysics that deals only with the high-frequency range, to about $10^{2} \mathrm{yr}$. It is perhaps a sign of the times, as we approach the end of the 20th century, that the old, rigid boundaries between the sciences are gradually breaking down. More and more we hear the call for interdisciplinary studies. These require a re-thinking of many educational curricula. Vita-Finzi deserves our heartfelt thanks for attempting to bring together some of the highly disparate aspects of the neotectonic spectrum. The book is unquestionably a "first." And he has done it very well.

The arrangement of the book is in nine chapters, taken more or less according to time-frames, from the low frequency to the high. Thus Chapter 2 deals with geological evidence, with faulting, for example, illustrated by the evidence of the Dead Sea rift, the North Anatolian Fault, the San Andreas rift and the Malta graben. Under the topic of warping, mention is made of Lake Bonneville, some details of the $\mathrm{R}^{\prime}$ mel anticline in Tunisia that is only about $100,000 \mathrm{yr}$ old, of the Hawke's Bay area of New Zealand, and of western Crete.

In Chapter 3, on archaeological and historical sources, Vita-Finzi is at his best, for he has spent much of his life studying the classical regions of the Mediterranean and Middle East. An interesting point he makes (not always appreciated by historians) is that "earthquakes, unlike wars and epidemics, appear to have little long-term social or economic impacts ..." So much for the controversies about Troy, Knossos and others. On the other hand, neotectonics are clearly responsible for the relative displacement of sea level (with a minor eustatic component) at many points around the world today (e.g. Mississippi delta, Chesapeake Bay, The Netherlands), and the book describes many interesting cases where studies have been made. These include the drowning of the lower Mesopotamian plain, Carthage, Roman fish-tanks around the Mediterranean, the dock at Louisbourg in Nova Scotia, Corinth, Caesarea (Israel), the Indus delta and Mohenjo-daro. Some alluvial-colluvial examples are given from Petra, Jericho, Tunisia and Algeria.

The author mentions the fascinating case of the Bardawil Lagoon on the north shore of Sinai, but avoids the temptation to discuss its possible association with Moses, the flight of the Israelites from Egypt, and the coincidental Thera tsunami - all of which make a gorgeous story, however difficult to substantiate. Nevertheless this reviewer, being very familiar with the area, is under the impression that the Biblical "Red Sea" was a translators' corruption of the "Sea of Reeds," which does apply to the Bardawil Lagoon, and it is true that the Thera tsunami was within a century of the Hebrew chronology.

Chapter 4 brings us to "Maps and Memories." Eye-witness reports certainly make great reading, but there is nothing like a personal experience of an earthquake or the evidence of careful mapping of an area recently involved. I still 
remember my childhood impressions of the total devastation of the city of Messina (Italy) by a major earthquake. Today, the television news makes it possible for almost everyone to appreciate some aspects of those awesome events. Monitoring rates of change is one of the available warning techniques, and the varied measuring devices are dealt with in Chapter 5. They include strain gauges and tilt meters, tide gauges and satellite surveillance, stress measurements and fault-plane solutions.

Actualistic catastrophism and uniformitarianism are reviewed in Chapter 6 on Geological Implications. The current hot-spot of the Strait of Hormuz is illustrated by a Landsat image, together with a first-hand discussion of the geomorphic landforms displayed. Geophysical implications are treated in Chapter 7 and introduced by a marvelously appropriate quotation from Lucretius (De Rerum Natura) that stresses the possibility of multiple, logical explanations for a single phenomenon. This is the place to talk about isostasy and mantle viscosity in Scandinavia and the Tibetan Plateau.

In Chapter 8, on seismology, seismic gaps and cycles, the author draws into the discussion again those examples described earlier in geological terms. The tricky business of prediction is entertainingly introduced in Chapter 9, with seismic zoning maps and the concepts of slip, creep and tilt.

This is a slim volume, easy to read, and a most valuable contribution to the interdisciplinary needs of modern educated men and women. It is not a technical handbook, but it should be on the required reading list of every geophysicist, geologist and physical geographer, both student and practitioner. It closes with a first-class reference list (1 8 pages), and a six-page index.

R.W. Fairbridge New York, U.S.A.

\section{GEOGRAFIA ECONOMICA: AREA DE RECURSOS MINERALES DE BOLIVIA-COLOMBIA-CHILE-ECUADOR- PANAMA-PERU-VENEZUELA}

M. Hermelin (ed.)

Instituto Internacional de Integracion, La Paz, Bolivia, 1986, $7 ! 5$ p., (P) $\$ 40$ (US)

This book is full of useful and interesting information. Written in Spanish, it is a compendium of the economic geology and current mineral statistics of the six Andean countries plus Panama. It is the result of an ambitious project undertaken by the Instituto Internacional de Integracion (III), an organization under the umbrella of the Andean Pact, with headquarters in La Paz, Bolivia. The work was the idea of Ramiro V. Paz C., III's Executive Director, and was steered through press under the editorship of Michel Hermelin in Medellin, Colombia.

The book is divided into nine chapters and two short appendices. Following a particularly lucid and succinct introductory chapter, each of the seven countries covered is treated in a chapter of its own. A final chapter on mineral marketing delves into economic systems, giving specific information on - $\mathrm{Ag}, \mathrm{Au}, \mathrm{Cu}, \mathrm{Li}, \mathrm{Sb}$, and $\mathrm{Sn}$, and concludes with notes on the operation of the London Metals Market and the New York Commodity Exchange. The first appendix discusses the eternal problem of how to classify resources and reserves, and the second is a brief and useful summary of how mineral deposits relate to plate tectonic theory.
One of the chief strengths of this compendium is that the subject is not the summary of an outside expert. Instead, each country is covered by one or more national specialists, chiefly geologists and mining engineers, all well versed and thoroughly familiar with their subject. The editor has achieved a degree of consistency virtually unknown in a work as diversified as this one. It could not have been an easy task to attain the uniformity whereby each of the seven county chapters is neatly subdivided into ten parts: background and general statistical information (including geography, demography, and economics), geomorphology and climate, geology, metallogenic provinces, metallic mineral deposits, nonmetallic mineral deposits, infrastructure (including human resources, transportation, and energy) mining history and current legislation, mining and the national economy, and outlook for the mining industry. Furthermore, these chapters are rich sources of references on geology and mining; in all, 82 pages of citations are given.

The book is relatively free of typographical and related errors. However, Figure 4-15 lacks a scale, many mines on Figure $7-8$ are seriously mislocated, and Figure $7-10$ is printed twice. The price of the book is excessive, however. Forty dollars (US) is bad enough, but 8000 Ecuadorian sucres, one million Peruvian soles, or 80 million Bolivian pesos may be beyond the reach of many Latin American professionals who, in fact, should have this functional and up-to-date reference at their fingertips.

For those interested in details, this book is a gold mine. You will learn that Chile exports nearly 3000 tons of iodine per year, how Ecuador got its name, and that Bolivia, once the largest producer of tin, has slipped to fifth place while becoming the chief supplier of antimony, with $27 \mathrm{~g}$ of world production. The largest known reserves of lithium are in the southern Andes, found there in brines associated with salars, an unusual geological environment.

Aside from the facets touched upon above, the book provides hundreds of maps and tables as well as such ancillary information as where geology and mining engineering are taught in each of the seven countries, and the impact of the mining industry on the respective national economies. At all levels, this is a valuable reference book. One hopes that the editor will have the patience and courage to bring it up-to-date every few years. Mining statistics become stale quickly.

T. Feininger

Ottawa, Canada

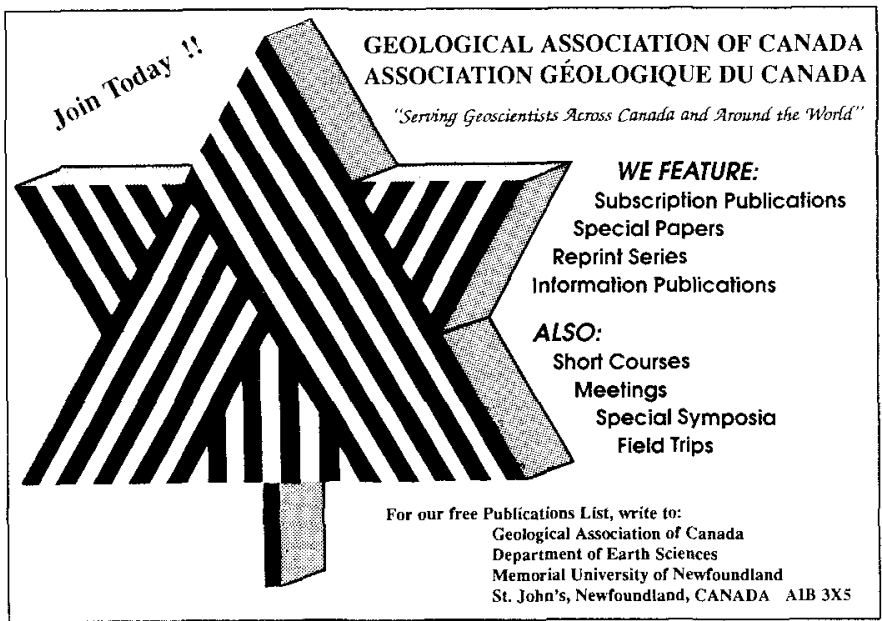

